\title{
BETWEEN SELF-ASSERTION AND DEFERENCE: EUROPEAN COURTS AND THEIR ASSESSMENT OF UN SECURITY COUNCIL RESOLUTIONS
}

\author{
Helmut Philipp AUST*
}

\begin{abstract}
RESUMEN: Las cortes europeas han enfrentado últimamente una serie de procedimientos en los que se cuestiona la debida aplicación de ciertas resoluciones del Consejo de Seguridad de Naciones Unidas. Esta contribución describe la actitud adoptada por el Tribunal de Primera Instancia de las Comunidades Europeas respecto a la implementación de las denominadas "sanciones dirigidas". A la fecha, dicho Tribunal ha omitido imponer estándares europeos a las acciones del Consejo de Seguridad, aunque, al mismo tiempo, ha afirmado los límites que establece el jus cogens a las facultades del mismo.
\end{abstract}

ABSTRACT: European courts have faced a number of judicial proceedings which challenge the implementation of UN Security Council resolutions. The contribution describes the attitude the European Court of First Instance has adopted towards the implementation of targeted sanctions. Up to now the European Court of First Instance has declined to impose European standards on the UN Security Council but has at the same time affirmed the jus cogens limits to the Council's powers.

RÉSUMÉ: Les Cours européennes ont été confrontées à un certain nombre de cas dans lesquels l'implémentation des résolutions du Conseil de Sécurité des Nations Unies est remise en cause. Cet article décrit l'attitude que le Tribunal de Première Instance européen a adoptée en ce qui concerne le problème des sanctions ciblées. Jusqu'à présent, ce Tribunal a refusé d'imposer des standards européens au Conseil de Sécurité mais a toutefois affirmé les limites de pouvoir du Conseil découlant du jus cogens.

* MLE, Doctoral Candidate and Fellow, Institute for International Law, University of Munich. Thanks for comments and criticism are due to Georg Nolte and Alejandro Rodiles who also provided for the Spanish abstract. Matthieu Clouqueur and Alexander Spencer helped with some language aspects. Some of the following considerations on the Yusuf and Kadi judgments are drawn from an article co-authored with Nina Naske: "Rechtsschutz gegen den UN-Sicherheitsrat durch europäische Gerichte? Die Rechtsprechung des EuG zur Umsetzunggezielter Sanktionen aus dem Blickwinkel des Völkerrechts", 61 Zeitschrift für Öffentliches Recht 2006, pp. 587-623. 


\section{SumMARY: I. Introduction. II. The Jurisprudence of the Euro- pean Community Courts. III. The European Court of Human \\ Rights. IV. Concluding Observations.}

\section{INTRODUCTION}

In recent UN Security Council practice, recourse to so-called "targeted" or "smart" sanctions has become a frequently used tool. In contrast to the comprehensive sanctions the Security Council employed in the 1990s, targeted sanctions aim at those which the Security Council deems as directly responsible for threats to the peace. Currently, there is a wide range of targeted sanctions in operation. ${ }^{1}$ They range from programmes which aim at restricting the use of funds and travel possibilities of individuals relatively close to the respective State government - as is the case in the sanctions programme against $\operatorname{Iran}^{2}-$ to the targeting of individuals which are allegedly supporters of international terrorism. So far, two sanctions regimes have been subject to judicial scrutiny by European courts which both belong to the latter category.

Security Council Resolution 1267 ordered States to freeze the assets of persons allegedly cooperating with the Afghan Taliban government. ${ }^{3}$ A list of persons was to be drawn up by a Sanctions Committee which was established as a subsidiary organ of the Security Council. ${ }^{4}$ In the following years, the Security Council repeatedly changed the sanctions regime. After the end of the Taliban regime in Afghanistan, the regime shifted its focus and was now geared towards al Qaeda itself. ${ }^{5}$ Over the lapse of time, exceptions to the freezing of assets were provided for hu-

1 See, e. g., UN Doc. S/RES/1521 (2003) on Liberia, S/RES/1533 (2004) on the Democratic Republic of Congo, S/RES/1572 (2004) on the Côte d'Ivoire, S/RES/1591 (2005) on the Sudan; for an overview see http://www.un.org/sc/committees/ (last visited 17 August 2007).

2 UN Doc. S/RES/1737 (2006), operative paragraph 12.

3 UN Doc. S/RES/1267 (1999).

4 On the Sanctions Committee see De Wet, Erika and Nollkaemper, André, "Review of Security Council Decisions by National Courts", 45 German Yearbook of International Law 2002, pp. 166-202, at p. 169; Cameron, Ian, "Targeted Sanctions and Legal Safeguards", 72 Nordic Journal of International Law 2003, pp. 159-214, at pp. 163 et seqq.

5 UN Doc. S/RES/1390 (2002). 
manitarian grounds (in order to ensure minimum living conditions) ${ }^{6}$ and a de-listing procedure was instituted. ${ }^{7}$ As the last procedural innovation, a so-called focal point was created in December 2006 to which listed individuals can communicate. ${ }^{8}$ This possibility is, however, not to be understood as a real chance for individuals to apply for a de-listing procedure. De-listing is still down to discretion of the members of the Sanctions Committee which exactly mirrors the composition of the Security Council. For de-listing (as well as for listing a person), consensus among the members of the Committee is required. ${ }^{9}$

The understanding of the Europan case law on the matter is overly complex for the reason that the relevant Security Council resolutions are not implemented domestically but within the framework of the European Union (EU). This leads to a situation where different levels of governance interact: the UN, the European and domestic levels respectively. Implementation at the European level follows a two-step process: First, the EU adopts a Common Position concerning restrictive measures against the Taliban or al Qaeda within the framework of the Union's Common Foreign Security Policy (CFSP). ${ }^{10}$ The CFSP, however, has an entirely intergovernmental character and has thus no supranational powers, i.e. the capacity to provide for direct effect within the EU Member States. ${ }^{11}$ To attain effects of this kind, action by the organs of the European Community (EC) is needed. This two-step process needs to be seen in the light of the peculiar institutional structure of the EU. Although legally distinct from the EC, the two form a common political unit which is often visualized as the EU being the roof above the different pillars of

6 UN Doc. S/RES/1452 (2002).

7 For an overview on the delisting procedure see para. 8 of the Guidelines of the Committee for the Conduct of its Work, adopted on 7 November 2002, as amended on 10 April 2003, 21 December 2005, 29 November 2006, 12 February 2007, available at http://www.un.org/sc/committees/1267/pdf/1267_guidelines.pdf (last visited 17 August 2007).

8 UN Doc. S/RES/1730 (2006); for more information on the Focal Point see http://www.un.org/sc/committees/dfp.shtml (last visited 17 August 2007).

9 Para. 4 a of the Guidelines of the Committee, op. cit., note 7.

10 Council of the European Union, Common Position 1999/727/CFSP, OJ 1999, L 294, p. 1 .

11 For the foundations of the doctrine of direct effect see ECJ, Van Gend en Loos v. Nederlandse Administratie der Belastingen, ECR 1963, 1 and Chalmers, Damian et al., European Union Law, Cambridge, Cambridge University Press, 2006, pp. 365 et seqq. 
cooperation provided for by the EC and the individual polities of the EU, i.e. the CFSP and "Justice and Home Affairs". For reasons which exceed the scope of this study, it has so far not been possible to "melt" the three pillars of European integration into one. ${ }^{12}$ The essential difference between the "EU pillar" and the "EC pillar" is the already mentioned supranational effect of EC legal acts. Accordingly, a regulation is adopted within the context of the EC which provides for the envisaged flight ban and freezing of funds of the Taliban/al Qaeda in Afghanistan. ${ }^{13}$ This procedure was repeated several times in order to keep the European implementation of the sanctions in line with the changing UN Security Council resolutions. ${ }^{14}$

The "1373-Regime" follows a different pattern. Laid down in Security Council resolution 1373 which was adopted at the end of September $2001,{ }^{15}$ general obligations for UN Member States to positively suppress the financing of terrorism were laid down. For a large part, the resolution transformed an international convention against the financing of terrorism which has not yet entered into force ${ }^{16}$ into binding international legal obligations by virtue of the Council's Chapter VII powers. This kind of legislative action poses problems for itself which shall however not be discussed here. ${ }^{17}$ What is interesting for our purposes, is that the EU/EC autonomously list suspected terrorists on the basis of Security Council resolution 1373. In order to comply with the obligation set forth by operative paragraph 1 lit. c of this resolution, a European sanctions regime

12 For an overview on this issue see Rodiles Bréton, Alejandro, Hacia una Constitución europea, Mexico, Porrúa, 2007, pp. 21 et seqq.

13 Regulation (EC) No. 337/2000, OJ 2000, L 43, p. 1.

14 The regulation which was the subject matter of the Yusuf and Kadi proceedings was Regulation (EC) No. 881/2002, OJ 2002, L 82, p. 1.

15 UN Doc. S/RES/1373 (2001), operative paragraph 1 lit. c.

16 International Convention for the Suppression of the Financing of Terrorism of 9 December 1999, not yet entered into force, available at http://untreaty.un.org/English/Terrorism/Conv12.pdf(last visited 17 August 2007).

17 Christakis, Théodore and Tercinet, Josiane, "Le pouvoir normatif du Conseil de Sécurité: le Conseil de Sécurité peut-il légiférer?", 37 Revue Belge de Droit International 2004, pp. 528-551; Nolte, Georg, "Lawmaking through the Security Council", in Wolfrum, Rüdiger and Röben, Volker (eds.), Developments of International Law in Treaty Making, Berlin, Springer, 2005, pp. 237-243; Talmon, Stefan, "The Security Council as World Legislature", 99 American Journal of International Law 2005, pp. 175-193. 
has been established. This was achieved through the adoption of two Common Positions in the framework of the EU's CFSP ${ }^{18}$ which were in turn implemented through a Regulation at the Community level. ${ }^{19}$ Here, the difference to the listings based on Security Council resolution 1267 is that it is not the Sanctions Committee of the Security Council which decides on the persons whose funds are to be frozen but rather that is the EU/EC which decides propriu motu. This necessitated further EC action through the means of Council decisions which lead to the listing of the persons or entities in question. ${ }^{20}$

In the context of the European Union (EU) individuals have raised the issue before the European Court of First Instance (ECFI). This Court has mostly condoned the way in which the sanctions were implemented. In the cases of Yusuf, ${ }^{21} \mathrm{Kadi},{ }^{22}$ Ayadi, ${ }^{23}$ and Hassan, ${ }^{24}$ the ECFI noted the limited scope of control it could exercise over the freezing of funds on the basis of the "1267-Regime". The Court limited its scrutiny to the question of whether the relevant resolutions violate rules of a jus cogens character. The appeals of the complainants are pending before the European Court of Justice (ECJ). In a subsequent judgment, concerning the

18 Common Position 2001/930/CFSP on combating terrorism, OJ 2001 L 344, p. 90; Common Position 2001/931/CFSP on the application of specific measures to combat terrorism, OJ 2001 L 344, p. 93.

19 Council Regulation (EC) No 2580/2001 of 27 December 2001, OJ 2001 L 344, p. 70 .

20 The first list was established by Council Decision 2001/927/EC of 27 December 2001, OJ 2001 L 344, p. 83.

21 ECFI, Ahmed Ali Yusuf and Al Barakaat International Foundation v. Council of the European Union and Commission of the European Communities, Case T-306/01, Judgment of the Court of First Instance of 21 September 2005, ECR 2005-II, 3533.

22 ECFI, Yassin Abdullah Kadi v. Council of the European Union and Commission of the European Communities, Case No. T-315/01, Judgment of the Court of First Instance of 21 September 2005, ECR 2005-II, 3649.

23 ECFI, Chafiq Ayadi v. Council of the European Union and Commission of the European Communities, Case No. T-253/02, Judgment of the Court of First Instance of 12 July 2006, not yet published in ECR.

24 ECFI, Faraj Hassan $v$. Council of the European Union and Commission of the European Communities, Case T-49/04, Judgment of the Court of First Instance of 12 July 2006, not yet published in ECR. 
Organisation des Modjahedines du peuple d'Iran, ${ }^{25}$ the ECFI was more willing to exercise judicial control as the listing of this organisation was not directly ordered by the UN Security Council but was autonomously done by the EU, albeit on the basis of UN Security Council Resolution 1373.

This is, however, not the only arena for judicial debate over UN Security Council action in Europe. The European Court of Human Rights (ECtHR) has not yet dealt with the problem of targeted sanctions itself. But it has left hints in its jurisprudence how it could treat the matter. The first relevant judgment concerned the rather classic, State-oriented UN sanctions; namely the ones against the former Federal Republic of Yugoslavia. The Court's Bosphorus ${ }^{26}$ ruling has frequently been interpreted as requiring a minimum standard with respect to human rights protection in the context of international cooperation. ${ }^{27} \mathrm{~A}$ more recent judgment concerning the exercise of governmental authority by France and Norway in the Kosovo under the auspices of UNMIK and KFOR however has put an emphasis on the limits of judicial scrutiny over UN Security Council action. $^{28}$

This contribution aims at providing an overview over the different approaches the ECFI and the ECtHR have thus far adopted in dealing with UN Security Council resolutions. It will highlight the pertinent issues, look for common features of the decisions and will try to identify the differences in reasoning. It asks the question how the European Courts have dealt with the problem of UN Security Council resolutions

25 ECFI, Organisation des Modjahedines du peuple d'Iran $v$. Council of the European Union, Case T-228/02, Judgment of the Court of First Instance of 12 December 2006, not yet published in ECR.

26 ECtHR, Bosphorus Hava Yollari Turizm ve Ticaret Anonim Sirketi v. Ireland, Judgment of 30 June 2005 (Grand Chamber), Application no. 45036/98, not yet published in ECHR, reprinted in 26 Human Rights Law Journal 2005, pp. 18-39.

27 Cabral Barreto, Ireneu, "La Cour européenne des droits de l'homme et le droit communautaire (Quelques réflexions à propos de l'arrêt Bosphorus)", in Kohen, Marcelo G. (ed.), Promoting Justice, Human Rights and Conflict Resolution through International Law, Liber Amicorum Lucius Caflisch, Leiden, Martinus Nijhoff, 2007, pp. 55-79, at p. 76; Hoffmeister, Frank, "Case Note", 100 American Journal of International Law 2006, pp. 442-449.

28 ECtHR, Agim Behrami and Bekir Behrami v. France and Ruzhdi Saramati $v$. France, Germany and Norway, Decision of Admissibility (Grand Chamber) of 31 May 2007, Application nos. 71412/01 and 78166/01, not yet published in ECHR. 
entering their legal systems: Have they adopted a position of self-assertion, upholding regional values over global cooperation or have they shown deference to the latter? Or have they possibly struck the right balance in choosing an intermediate way between these two alternatives?

\section{THE JURISPRUDENCE OF THE EUROPEAN COMMUNITY COURTS}

\section{The Yusuf and Kadi Cases}

The ECFI first pronounced on the implementation of the so-called targeted sanctions in the largely parallel Yusuf and Kadi cases. ${ }^{29}$ The relevant EC regulations were challenged on three grounds. First, the applicant asserted a lack of competence on the side of the EC to implement the Common Positions of the Union's CFSP. ${ }^{30}$ The Court did not follow him in this regard for complex reasons of EC law which are not of particular relevance for our purposes. ${ }^{31}$ The same can be said of the second

29 See op. cit., notes 21 and 22.

30 The applicant did not view Articles 301 and 60 TEC as providing a sufficient basis for the enactment of the sanctions. Article 301 TEC provides: 'Where it is provided, in a common position or in a joint action adopted according to the provisions of the Treaty on the European Union relating to the common foreign and security policy, for an action by the Community to interrupt or to reduce, in part or completely, economic relations with one or more third countries, the Council shall take the necessary urgent measures.' Article 60, para. 1 TEC provides: 'If, in the cases envisaged in Article 301, action by the Community is deemed necessary, the Council may, in accordance with the procedure provided for in Article 301, take the necessary urgent measures on the movement of capital and on payments as regards the third countries concerned.' Obviously, those two provisions aim at taking measures against "third countries" by which was meant third States. As long as the sanctions regime was directed against the Taliban and those associated with them, it was relatively easy to subscribe to the view that the Community had a competence to impose sanctions against persons or entities closely associated with the Taliban, the de facto-government of Afghanistan at the time. After the fall of the Taliban regime, however, the basis for the sanctions regime needed to change as the sanctions could no longer be understood as to be directed against a third State.

31 The ECFI resorted to Article 308 TEC ('If action by the Community should prove necessary to attain, in the course of the operation of the common market, one of the objectives of the Community, and this Treaty has not provided the necessary powers, the Council shall, acting unanimously on a proposal from the Commission and after consulting the European Parliament, take the appropriate measures.') which allows for flexible action of the EC, see ECFI, Yusuf, op. cit., note 21, paras. 153 et seqq.; for a critical assessment of this move see Tomuschat, Christian, "Case Note", 43 Common Market Law 
ground on which the applicant challenged the legality of the regulation concerned: He saw a violation of Article $249^{32}$ of the Treaty Establishing the European Community (TEC) as in his view the regulation at stake did not provide for general application which he deemed as a prerequisite for a regulation. Instead, he viewed the listing as some form of administrative action which would thus have entailed the necessity of a decision. The Court disposed of this issue by remarking that the regulation did have a general scope of application as it prohibits anyone to make available funds or economic resources to certain persons or entities. ${ }^{33}$ The Court remarked that the argument of the applicant stemmed "from a confusion of the concept of the addressee of an act with the concept of the object of that act". ${ }^{34}$

At the centre of the case stood the applicants' assertions concerning an alleged breach of fundamental rights. The respective fundamental rights find their legal basis in Article 6, para. 2 of the Treaty Establishing the European Union (TEU) as well as in the jurisprudence of the European Court of Justice. Article 6, para. 2 provides that: "The Union shall respect fundamental rights, as guaranteed by the European Convention for the Protection of Human Rights and Fundamental Freedoms signed in Rome on 4 November 1950 and as they result from the constitutional traditions common to the Member States, as general principles of Community law".

Before the Court could turn to the substantive issues, it needed to determine its own competence. It found: "The Court can properly rule on the plea alleging breach of the applicants' fundamental rights only in so far as it falls within the scope of its judicial review and it is capable, if proved, of leading to annulment of the contested regulation". 35

This is due to the fact that the relevant EC regulations transmit the UN Security Council resolutions into the European legal order. They do

Review 2006, pp. 537-551, at p. 540; Sciso, Elena, "Fundamental Rights and Article 103 of the UN Charter before the Court of First Instance of the European Communities", 15 The Italian Yearbook of International Law 2005, pp. 137-151, at pp. 138 et seqq.

32 Article 249 TEC reads in relevant parts: "A regulation shall have general application. It shall be binding in its entirety and directly applicable in all member States... A decision shall be binding in its entirety upon those to whom it is addressed". Emphasis added, see on this distinction Douglas-Scott, Sionaidh, Constitutional Law of the European Union, Harlow, Pearson, 2002, pp. 110 et seqq.

33 ECFI, Yusuf, op. cit., note 21, para. 186.

34 Ibidem, para. 187.

35 Ibidem, para. 226. 
so in such a close manner that judicial review of those resolutions would have implicitly resulted in judicial review of the UN Security Council. This raises a preliminary issue: Why is the EC bound to UN law in the first place?

\section{A. The Relationship Between UN Law and EU/EC Law}

The UN Charter is only binding upon Member States. ${ }^{36}$ Therefore, the Court took a rather sweeping approach by first examining the relationship between UN law and EU/EC law. ${ }^{37}$ The Court started with an assessment from the standpoint of international law and noted that - seen from this perspective-

The obligations of the Member States of the United Nations under the Charter of the United Nations clearly prevail over every other obligation of domestic or of international treaty law including, for those of them that are members of the Council of Europe, their obligations under the ECHR and, for those that are also members of the Community, their obligations under EC law. ${ }^{38}$

To justify this finding, the Court pointed towards Articles 25 and 103 of the UN Charter ${ }^{39}$ as well as - rather oddly - to Article 27 of the Vienna Convention on the Law of Treaties which provides that a party may not invoke the provisions of its internal law as a justification for its failure to perform a treaty. ${ }^{40}$

As this array of rules describes the international law viewpoint, the Court then proceeded to the EC law level. Article 307, para. 1 TEC provides that: " $(\mathrm{t})$ he rights and obligations arising from agreements concluded before 1 January 1958, or for acceding States, before the date of their accession, between one or more Member States on the one hand,

36 In addition, the UN Charter also envisages non-members to be bound, see Article 2, para. 6 of the Charter, see on this provision Fassbender, Bardo, "The Charter of the United Nations as Constitution of the International Community", 36 Columbia Journal of Transnational Law 1997, pp. 529-620, at pp. 593 et seq.

37 ECFI, Yusuf, op. cit., note 21, paras. 228 et seqq.

38 Ibidem, para. 231.

39 The Court adds that the primacy just mentioned also extends to decisions contained in resolutions of the UN Security Council, ibidem, para. 234.

40 Ibidem, paras. 232 et seqq. 
and one or more third countries on the other, shall not be affected by the provisions of this Treaty".

The Court therefore offered two perspectives on the primacy of UN law over EC law: It referred both to the rules of the UN legal system which provide for this primacy as well as to the provision of the TEC. In this connection, the Court remarked that "pursuant both to the rules of general international law and to the specific provisions of the Treaty, Member States may, and indeed must, leave unapplied any provision of Community law" which would contravene the fulfilment of their obligations under the UN Charter. ${ }^{41}$

One may wonder about the reasons for this dual affirmation of primacy. The Court did not clearly show which one of the two reasons is the relevant one. Seen from the perspective of the UN Charter, no additional affirmation of its primacy in the TEC would be necessary. By leaving this question open the Court allows for some uncertainty whether there is real primacy of UN law over EC law or whether it is just voluntary subordination. On the other hand it needs to be understood that the Court was not eager to choose between a monist or dualist conception of the relationship between UN and EC law. What counts is therefore that the ECFI was willing to accept the primacy of UN law.

In addition, the reference to Article 307 TEC may have been motivated to overcome another complexity of the case. As was already mentioned above, the UN Charter itself does not bind the EC. Hence, the Court noted that "unlike its Member States, the Community as such is not directly bound by the Charter of the United Nations" (my emphasis). ${ }^{42}$ It is interesting that the Court qualified its own finding in such a way. How can the EC be bound — not as such — in an indirect way? The Court assumed that the Community "must be bound by the obligations under the Charter of the United Nations in the same way as its Member States, by virtue of the Treaty establishing it". ${ }^{43}$ To reach this conclusion, the Court found "a duty on the part of the institutions of the Community not to impede the performance of the obligations of Member States which stem from that Charter". ${ }^{44}$ Therefore, it is a duty of loyalty be- 
tween the different components of the EU/EC which necessitates the binding effect of the UN Charter on the EC.

\section{B. The Scope of Judicial Review}

What practical consequences flow from this demarcation between the UN and EC law? With respect to the scope of judicial review the ECFI can engage in, the Court resorted to a higher form of dialectics. In a two step process, it first determined that: "any review of the internal lawfulness of the contested regulation... would therefore imply that the Court is to consider, indirectly, the lawfulness of those [UN Security Council, my addendum] resolutions". ${ }^{45}$

Taking up its previous reasoning on the relationship between UN law and EC law, the Court found that to exercise judicial review over the contested regulations would both violate the obligations of the Member States under the UN Charter and be contrary to EC law. ${ }^{46}$ After those findings, the Court played an extraordinary trick: "None the less, the Court is empowered to check, indirectly, the lawfulness of the resolutions of the Security Council in question with regard to jus cogens". ${ }^{47}$

Nothing indicated beforehand that the Court would take this turn. The findings of the Court as to the relationship between UN law and jus cogens which follow are rather sketchy. The Court was of the opinion that the UN Charter presupposes the existence of mandatory principles of international law, ${ }^{48}$ a rather delicate assumption as the concept of jus cogens first saw the light of day in the Vienna Convention on the Law of Treaties of $1969 . .^{49}$ It is submitted here that the finding of the Court is

45 Ibidem, para. 266.

46 Ibidem, paras. 273 et seq.

47 Ibidem, para. 277.

48 Ibidem, para. 279. In para. 280, the Court further points towards the principles and purposes of the UN which are binding on the bodies of the UN as well (Article 24, para. 2 of the UN Charter).

49 Articles 53 and 64 of the Vienna Convention on the Law of Treaties. For concise accounts on jus cogens in present international law see Orakhelashvili, Alexander, $\mathrm{Pe}$ remptory Norms in International Law, Oxford, Oxford University Press, 2006; Paulus, Andreas L., "Jus Cogens in a Time of Hegemony and Fragmentation - An Attempt at Reappraisal", 74 Nordic Journal of International Law 2005, pp. 297-333; and the contributions in Tomuschat, Christian and Thouvenin, Jean-Marc (eds.), The Fundamental Rules of the International Community, Leiden, Martinus Nijhoff, 2005. 
correct but badly argued. It is correct insofar as a category of jus cogens which is taken seriously necessarily means that also the UN Security Council is bound by it. Whereas it is plausible that the Security Council can override treaty law and other customary international law, ${ }^{50}$ it is widely held that the Council is bound to jus cogens. ${ }^{51}$ Whether this also means that a regional court is competent to decide over the limits jus cogens imposes on the Security Council is however not so clear. ${ }^{52}$ It is this point which would have needed more attention by the ECFI. Review by regional courts may have a deterring effect on the system of collective security as established by the UN Charter. It could give other Member States of the UN a reason not to comply with binding Chapter VII resolutions. On the other hand, a jus cogens limit on the Security Council's powers which is completely unchecked would make no sense either. ${ }^{53}$ There is support for the argument that States may refuse to comply with

50 Dugard, John, "Judicial Review of Sanctions", in Gowlland-Debbas, Vera (ed.), United Nations Sanctions and International Law, The Hague, Martinus Nijhoff, 2001, pp. 83-91, at p. 89; Reisman, W. Michael, "The Constitutional Crisis in the United Nations", 87 American Journal of International Law 1993, pp. 83-100, at p. 93; De Wet, Erika, The Chapter VII Powers of the United Nations Security Council, Oxford, Hart Publishing, 2004, p. 187; for the opposite opinion see Doehring, Karl, "Unlawful Resolutions of the Security Council and their Legal Consequences", 1 Max Planck Yearbook of United Nations Law 1997, pp. 91-109, at p. 98.

51 ICJ, Case Concerning Application of the Convention on the Prevention and Punishment of the Crime of Genocide (Bosnia and Herzegovina v. Yugoslavia (Serbia and Montenegro)), Further Request for the Indication of Provisional Measures, Order of 13 September 1993, sep. op. of Judge ad hoc Elihu Lauterpacht, ICJ Reports 1993, 407, para. 100; Gowlland-Debbas, Vera, "The Functions of the United Nations Security Council in the International Legal System", in Byers, Michael (ed.), The Role of Law in International Politics, Oxford, Oxford University Press, 2000, pp. 277-313, at p. 305; Orakhelashvili, Alexander, op. cit., note 49, pp. 423 et seqq.; Reinisch, August, "Developing Human Rights and Humanitarian Law Accountability of the Security Council for the Imposition of Economic Sanctions", 95 American Journal of International Law 2001, pp. 851-872, at p. 859; De Wet, Erika, op. cit., note 50, p. 187; for a different account see Fassbender, Bardo, "Quis judicabit? The Security Council, Its Powers and Its Legal Control”, 11 European Journal of International Law 2000, pp. 219-232, at p. 227.

52 Bulterman, Mielle, "Fundamental Rights and the United Nations Financial Sanctions Regime: The Kadi and Yusuf Judgments of the Court of First Instance of the European Communities", 19 Leiden Journal of International Law 2006, pp. 753-772, at p. 768.

53 Although it needs to be admitted that the Security Council's interpretation of what constitutes jus cogens weighs heavy too, see Paulus, Andreas L., op. cit., note 49, p. 317. 
Security Council resolutions as a matter of last resort if they contravene jus cogens. ${ }^{54}$ If this is true there are only arguments of limited force which speak against the competence of courts to contribute to this process. It may even be preferable to have a Court pronounce itself on the issue. ${ }^{55}$

\section{The Judicial Review Finally Enacted}

What makes those assumptions appear somehow flawed is the turn the ECFI took after having thus determined its scope of judicial review. The Court took note of the three fundamental rights the applicants have raised which are the right to make use of their property, the right to a fair hearing and the right to an effective judicial remedy. Now those are important human rights with respect to both treaty law as well as custom. It is however already problematic whether international human rights law includes a right to a fair hearing in administrative proceedings. International human rights treaties only provide for a right to a fair trial. ${ }^{56}$ What is obvious however is that the rights mentioned as such do not possess a status of jus cogens. Only the most fundamental rules of the international community are counted among those rules. They regularly include the prohibition of aggression, genocide, slavery, piracy, torture as well as the most fundamental rules of human rights law and international humanitarian law. ${ }^{57}$ Nonetheless, the Court checked the regulation against the three fundamental rights invoked. In the end, it came to the right conclusion that none of the three rights enjoys a status of jus cogens. The

54 Doehring, Karl, op. cit., note 50, pp. 105 et seqq.; De Wet, Erika and Nollkaemper, André, op. cit., note 4, p. 198; Herdegen, Matthias, "Review of the Security Council by National Courts: A Constitutional Perspective", in De Wet, Erika and Nollkaemper, André (eds.), Review of the Security Council by Member States, Antwerp, Intersentia, 2003, pp. 77-84; Nolte, Georg, "The Limits of the Security Council's Powers: Some Reflections", in Byers, Michael (ed.), The Role of Law in International Politics, Oxford, 2000, pp. 315-326, at p. 319; Orakhelashvili, Alexander, op. cit., note 49, pp. 477 et seqq.

55 De Wet, Erika and Nollkaemper, André, op. cit., note 4, p. 199.

56 Article 14 of the International Covenant on Civil and Political Rights, Article 8, para. 1 of the American Convention on Human Rights, Article 7 of the Banjul Charter on Human and Peoples' Rights, Article 6 ECHR.

57 Brownlie, Ian, Principles of Public International Law, 6th ed., Oxford, Oxford University Press, 2003, pp. 488 et seq.; Kadelbach, Stefan, Zwingendes Völkerrecht, Berlin, Duncker \& Humblot, 1992, pp. 314 et seq.; Orakhelashvili, Alexander, op. cit., note 49 , pp. 50 et seqq. 
Court however left it open whether there is a jus cogens right not be "arbitrarily deprived of his property". ${ }^{58}$ This formulation is inspired by Article 17 of the Universal Declaration of Human Rights ${ }^{59}$ which is most arguably not a good source to discover new jus cogens rules in. The way in which the ECFI treated the complaints about alleged breaches of fundamental rights is therefore quite peculiar: The Court pretended to scrutinize the contested regulation against some form of fundamental rights which could at the same time never match the standards set forth in the earlier passages of the judgment. Judicial review of this kind could be seen as a mere placebo.

\section{The Ayadi and Hassan Cases}

The Ayadi ${ }^{60}$ and Hassan ${ }^{61}$ cases which the ECFI decided in June 2006 in general follow the Court's earlier approach in Yusuf and Kadi. However, they include an interesting passage on the position of the individuals listed by the UN Security Council. The ECFI held that States are under an obligation to effect "diplomatic protection" for listed persons of their nationality in the way that: "States are required to act promptly to ensure that such persons' cases are presented without delay and fairly and impartially to the [Sanctions - my addendum] Committee, with view to their re-examination". 62

This statement is innovative in two ways: First of all, it is stunning that the ECFI drew on EU/EC law to develop this individual right. The Court pointed to Article 6 TEU which provides that Member States are bound to respect the fundamental rights as guaranteed by the European Convention on Human Rights and as they result from the constitutional traditions common to the Member States which thus constitute general principles of Community law. ${ }^{63}$ The second innovation is the obligation to exercise diplomatic protection. While it is not diplomatic protection in the true sense, the kind of protective action demanded by the ECFI certainly comes close to it. Traditionally, it is in the State's discretion

58 ECFI, Yusuf, op. cit., note 21, para. 292.

59 Resolution of the UN General Assembly of 10 December 1948.

60 ECFI, Ayadi, op. cit., note 23.

61 ECFI, Hassan, op. cit., note 24.

62 Ibidem, para. 119.

63 Ibidem, para. 116. 
whether or not to exercise such protection. ${ }^{64}$ This approach is still reflected in Article 2 of the 2006 Draft Articles on Diplomatic Protection as adopted by the International Law Commission (ILC). ${ }^{65}$ However, the ILC made also reference to more progressive developments which could give rise to the impression that there are "some obligations, however limited, either under national or international law, on the State to protect its nationals abroad when they have been subjected to serious violations of their human rights". ${ }^{66}$ As the ILC did not arrive at a definite conclusion in this regard, ${ }^{67}$ it included Draft Article 19 on recommended practice which spells out that a "State entitled to exercise diplomatic protection according to the present draft articles, should: (a) Give due consideration to the possibility of exercising diplomatic protection, especially when a significant injury has occurred". ${ }^{68}$

While the ECFI had already included the right to diplomatic protection in its Yusuf and Kadi judgments, ${ }^{69}$ its findings in Ayadi and Hassan are more detailed and far-reaching. In addition to the basic right to diplomatic protection, the Court also held that: "the Member States must thus ensure, so far as is possible, that interested persons are put in a position to assert their view before the competent national authorities when they present a request to be removed from the list". ${ }^{70}$

The Court cited two authorities for its approach. First, it made reference to the Tribunal of First Instance of Brussels which ordered the Belgian State to exercise diplomatic protection in a sanctions case. ${ }^{71}$ Second, it pointed to established jurisprudence of the European Court of Justice according to which:

64 Verdross, Alfred and Simma, Bruno, Universelles Völkerrecht, 3er. ed., Berlin, Duncker \& Humblot, 1984, § 1228.

65 UN Doc. A/61/10, paras. 50 et seqq.

66 Commentaries on the Draft Articles on Diplomatic Protection, ibidem, art. 2, para. 3.

67 See Vermeer-Künzli, Annemarieke, "Restricting Discretion: Judicial Review of Diplomatic Protection", 75 Nordic Journal of International Law 2006, pp. 279-307 for an overview of domestic decisions on the matter.

68 Op. cit., note 65.

69 ECFI, Yusuf, op. cit., note 21, paras. 309 et seqq., 317 et seq.

70 ECFI, Hassan, op. cit., note 24, para. 117.

71 ECFI, Ayadi, op. cit., note 23, para. 150 with reference to Tribunal de première instance de Bruxelles, Fourth Chamber, Nabil Sayadi and Patricia Vinck $v$. Belgian State, judgment of 11 February 2005. 
In the absence of Community provisions it is for the domestic legal system of each Member State to determine the detailed procedural rules governing actions at law intended to safeguard the rights which individuals derive from the direct effect of Community law. The Court has made it clear that those rules cannot be less favourable than those governing rights which originate in domestic law (principle of equivalence) and that they cannot render virtually impossible or excessively difficult the exercise of rights conferred by Community law (principle of effectiveness). ${ }^{72}$

Now according to this jurisprudence, the question is exactly what the domestic legal systems prescribe. To assume an individual right to diplomatic protection is a progressive position. To take the example of German constitutional law, the jurisprudence of the Federal Constitutional Court is ready to accept a fundamental right to diplomatic protection flowing from the State's positive obligations under the Basic Law. This right is, however, subject to the important limitation that it is ultimately within the State's discretion as to the question of how this right shall be exercised. ${ }^{73}$

One can only speculate about the intentions underlying this addition to the ECFI's jurisprudence. One motive may be the criticism the Court has faced for not effectively protecting human rights through its bow towards UN Security Council resolutions. ${ }^{74}$ In the way the ECFI has now dealt with the question of diplomatic protection it somehow delegated

72 ECJ, Götz Leffler v. Berlin Chemie AG, Case C-443/03, Grand Chamber, Decision of 8 November 2005, ECR 2005-I, 9611, paras. 49 and 50.

73 German Federal Constitutional Court, Decision of 16 December $1980=$ BVerfGE 55, 349, 367, see also Klein, Eckart in Ress, Georg and Stein, Thorsten (eds.), Der diplomatische Schutz im Völker- und Europarecht, Baden-Baden, Nomos, 1992, pp. 125-136, at pp. 130 et seqq.; Kleinlein, Thomas and Rabenschlag, David, "Auslandsschutz und Staatsangehörigkeit", 67 Zeitschrift für ausländisches öffentliches Recht und Völkerrecht 2007, forthcoming (on file with the author).

74 For critical accounts of the Yusuf and Kadi judgments see Harings, Lothar, "Die EG als Rechtsgemeinschaft?”, Europäische Zeitschrift für Wirtschaftsrecht 2005, p. 705; Karayigit, Mustafa T., "The Yusuf and Kadi Judgments: The Scope of the EC Competences in Respect of Restrictive Measures", 33 Legal Issues of Economic Integration 2006, pp. 379-404, at p. 404; Lavranos, Nikolaos, "Sanctions and Judicial Review", 76 Nordic Journal of International Law 2007, pp. 1-17, at p. 16; Payandeh, Mehrdad, "Rechtskontrolle des UN-Sicherheitsrates durch staatliche und überstaatliche Gerichte", 66 Zeitschrift für ausländisches öffentliches Recht und Völkerrecht 2006, pp. 41-71, at pp. 69 et seq.; Sciso, Elena, op. cit., note 31, pp. 148 et seqq. 
the problem of effective human rights protection to the level of the Member States. This approach is worthy of doubt as it eventually amounts to stipulating that the Member States are responsible for curing deficiencies in terms of human rights which have been caused at a higher level - first at the global level of the UN Security Council and then at the supranational one of the European Communities. The whole jurisprudence of the ECFI with regard to the "1267-regime" rests on the assumption that there is no margin of appreciation for the Community nor for the Member States to implement the relevant sanctions. At the same time, it is however laudable as the ECFI imposes an obligation on EU Member States to take up all political means at their disposal for the protection of individuals listed. In the context of the limited judicial avenues individuals or entities have when they are listed, it is necessary to think of creative means by which a maximum of legal protection can be afforded for the ones listed without calling into question the coherence of the UN sanctions regime.

\section{The Organisation des Modjahedins du Peuple d'Iran Case}

That the ECFI is willing to exercise more protection of fundamental rights once it is faced with sanctions which are not directly based on UN Security Council resolutions is aptly shown by the December 2006 judgment in the case concerning the "Organisation des Modjahedines du peuple d'Iran (People's Mujahidin of Iran, Mujahedin-e Khalq in Farsi)" (in the following OMI). ${ }^{75}$ This entity was listed on the basis of the so-called "1373-regime". ${ }^{76}$ There, as we may recall, the listings are effectuated not directly by the UN Security Council but by the implementing States or supranational organisations. The applicant challenged the Common Position which originated from the domain of the CFSP as well as the decision which implemented it at the Community level. According to its longstanding jurisprudence, the ECFI declined to exercise jurisdic-

75 ECFI, Organisation des Modjahedines, op. cit., note 25.

76 Common Position 2002/340/CFSP, updating Common Position 2001/931 (OJ 2002 L 116, p. 75) and Council Decision 2002/334/EC of 2 May 2002 implementing Article 2(3) of Regulation (EC) No 2580/2001 and repealing Decision 2001/927 (OJ 2002 L 116, p. 33). 
tion over the CFSP acts. ${ }^{77}$ However, the ECFI did proceed with an examination of the implementing decision which stems from the Community pillar and is subject to judicial review by the Community courts.

The applicant raised three issues with the Court. The main complaint related to an infringement of the right to a fair hearing which was the only ground the Court considered. ${ }^{78}$ After defining the principal scope of the right to a fair hearing under Community law, the Court noted the important differences between the "1267-regime" and the "1373-regime":

Since the identification of the persons, groups and entities contemplated in Security Council Resolution 1373 (2001), and the adoption of the ensuing measure of freezing funds, involve the exercise of the Community's own powers, entailing a discretionary appreciation by the Community, the Community institutions concerned, in this case the Council, are in principle bound to observe the right to a fair hearing of the parties concerned when they act with a view to giving effect to that resolution. ${ }^{79}$

The Court arrived at the conclusion that the Council decision was to be annulled. This finding was motivated by the fact that the Council did not give sufficient reasons for the listing of the OMI. ${ }^{80}$ Furthermore, the Court found that a hearing could have been effectuated after the listing procedure was completed as then there was no danger of the efficiency of the listing being hampered. ${ }^{81}$ That the decision was annulled was also due to the fact that the Court did not see itself in the position to engage in a substantive review of the listing of the OMI. ${ }^{82}$ It plainly had not enough information at hand as to engage in this task. Applying what

77 ECFI, Organisation des Modjahedins, op. cit., note 25, para. 60. In this respect, some new developments in the jurisprudence of the ECJ should be noted. In two decisions from February 2007 the ECJ now came to the conclusion that acts of the CFSP could be subjected to judicial review if they have a direct effect on individuals, ECJ, Gestoras Pro Amnistía and others $v$. Council of the European Union, Case C-354/04 P, Judgment of the Grand Chamber of 27 February 2007; ECJ, Segi and others $v$. Council of the European Union, Case C-355/04 P, Judgment of the Grand Chamber of 27 February 2007.

78 Two other pleas were based on an infringement on the right to revolt against tyranny and oppression and finally a violation of the right to non-discrimination.

79 ECFI, Organisation des Modjahedins, op. cit., note 25, para. 117.

80 Ibidem, paras. 138 et seqq.

81 Ibidem, para. 131.

82 Ibidem, para. 173. 
could be termed a in dubio pro libertate maxim, the Court thus opted for the annulment of the decision and therefore struck away the basis for the listing of the OMI. This jurisprudence has since then been confirmed in another case. ${ }^{83}$

Although perfectly understandable from a legal perspective it is nonetheless curious that the degree of legal protection listed persons or entities may benefit from depends on the fact whether they have been listed by the UN Security Council itself or by the EU. ${ }^{84}$ In practical terms, the jurisprudence of the ECFI may very well lead to a stronger shift towards the UN Security Council as States which wish to propose a person or entity for listing will deem this avenue as safer and more reliable.

\section{THE EUROPEAN COURT OF HUMAN RIGHTS}

The ECtHR has thus far not pronounced itself on the matter of targeted sanctions. Nonetheless, the jurisprudence of the ECtHR merits special attention for our case as it has dealt in other contexts with the implementation of UN Security Council resolutions through the European Community and with the scrutiny of acts attributable to the UN in the Serbian province of Kosovo, i.e. also situation in which UN Security Council resolutions are at stake.

\section{The Case of Bosphorus v. Ireland}

The Bosphorus Case of the Grand Chamber of the European Court of Human Rights is predated by a laborious strain of different cases before Irish and Community courts. ${ }^{85}$ Without wanting to enter into the details of the dispute, it should be noted that the case falls within the framework of the sanctions against the then Federal Republic of Yugoslavia. The complainant, a Turkish-based airline had rented two Boeing 737 air-

83 ECFI, Jose Marion Sison v. Council of the European Union, Case T-47/03, Judgment of 11 July 2007.

84 Haltern, Ulrich, "Gemeinschaftsgrundrechte und Antiterrormaßnahmen der UNO“, Juristenzeitung 2007, pp. 537-547, at p. 544; Lavranos, Nikolaos, op. cit., note 74 , p. 17.

85 For references to the Irish and EC Court proceedings see ECtHR, Bosphorus, op. cit., note 26, paras. 33 et seqq. 
crafts from JAT, the national airline of Former Yugoslavia. Part of the UN sanctions programme was that States should not allow aircrafts operated from or on behalf or registered in the Federal Republic of Yugoslavia to take off or land or be provided with engineering or maintenance services. ${ }^{86}$

A later resolution further ordered States to impound all aircraft in their territory "in which a majority or controlling interest is held by a person or undertaking in or operating" from the Federal Republic of $\mathrm{Yu}$ goslavia. ${ }^{87}$ This resolution was implemented on the EC level by means of a regulation. ${ }^{88}$ The two aircrafts happened to be in Dublin for maintenance in January 1993 and were not allowed to take off again.

The core issue before the ECtHR was whether Ireland had violated its obligations under Article 1 of the First Additional Protocol to the ECHR by cooperating within the framework of international organizations which do not provide for sufficient means of human rights protection. The Court held that there is a presumption that the member State has not departed from its obligations under the Convention: "as long as the relevant organisation is considered to protect fundamental rights, as regards both the substantive guarantees offered and the mechanisms controlling their observance, in a manner which can be considered at least equivalent to that for which the Convention provides". ${ }^{89}$

Checking upon whether the EC system meets those conditions, the ECtHR looked meticulously into the different procedural means the TEC provides for the protection of individual rights. The ECtHR first noted that the constituent EC treaty did not provide for the protection of fundamental rights in the very initial stages of the European integration. ${ }^{90}$ However, the ECJ subsequently recognized fundamental rights as general principles of EC law and this development was then enshrined in the legal texts of the EC. The ECtHR was not satisfied by the mere guarantees of fundamental rights but stressed the fact that "the effectiveness of such substantive guarantees depends on the mechanisms of control in

87 UN Doc. S/RES/820 (1993).

88 EC Regulation 990/93, OJ L 102/14 (1993).

89 ECtHR, Bosphorus, op. cit., note 26, para. 155.

90 Ibidem, para. 159. 
place to ensure observance of such rights". ${ }^{91}$ Although the ECtHR noted that the access of individuals to the ECJ is limited under the terms of the TEC, it was satisfied by the combined possibilities of individuals to afford themselves legal protection before Community as well as domestic courts. ${ }^{92}$ Thus, the Court found the level of protection provided by the EC courts as equivalent to the one required by the European Convention. ${ }^{93}$

This test of equivalent protection stands in the tradition of the Court's jurisprudence that international co-operation is generally welcome but shall not lead to the abandonment of ECHR obligations. ${ }^{94}$ This was most clearly mentioned in the Matthews Case where the Court held in the context of the elections to the European Parliament that Contracting States remain responsible for guaranteeing rights even if they engage in international co-operation. ${ }^{95}$

What does this tell us for the question of targeted sanctions? It seems fair to say that the targeted sanctions regime as it stands now would not prima facie stand the test of equivalent protection. To apply the test to targeted sanctions presupposes, however, a complex legal operation. First, it needs to be distinguished which organisational level is concerned. With respect to the European Community legal system, the general conclusions the Court reached in Bosphorus could apply. Due to the limited degree of judicial scrutiny the ECFI has set out, it could however be called into question whether fundamental rights are still protected in an equivalent manner within the EC system. As far as the UN level is concerned, it is even more difficult in the first place to make out equivalent protection of fundamental rights.

Secondly, the equivalent protection test would need further clarification in order to be applied to the problem of targeted sanctions. As it

91 Ibidem, para. 160.

92 Ibidem, paras. 162 et seqq.

93 Ibidem, para. 165.

94 For an overview see Ovey, Clare and White, Robin C. A., Jacobs \& White's The European Convention on Human Rights, 4th. ed., Oxford, Oxford University Press, 2006, pp. 29 et seqq.

95 ECtHR, Matthews $v$. The United Kingdom, Application No. 24833/94, Grand Chamber, Judgment of 18 February 1999, ECHR 1999-I, 251, para. 32; see also ECtHR, Waite and Kennedy v. Germany, Application No. 26083/94, Grand Chamber, Judgment of 18 February 1999, ECHR 1999-I, 393, para. 67. 
leads to a presumption that the States parties did not depart from the standard the ECHR sets forth, also a negative finding in this regard need not be the last word on the matter. If the equivalent protection test leads to negative results, is then an additional balancing process conceivable which could result in the finding that (1) yes, States parties have left behind the framework the Convention sets forth and (2) nonetheless this was justified for the sake of overriding community concerns?

This leads, thirdly, to the consideration that arguably the $\mathrm{UN}$ is a special case. It should be taken into account that the Bosphorus Case only dealt with human rights protection within the EC. The Court did not erect a test of equivalent protection with respect to the $\mathrm{UN}$ and cautiously avoided to pronounce on this issue. ${ }^{96}$ Article 103 of the Charter establishes that obligations resulting out of the Charter shall prevail over any other treaty obligations of the UN member States. In its al-Adsani case, the ECtHR has held that the ECHR is not be interpreted in a vacuum and affirmed the importance of the law of State immunity for today's international legal order in the face of susceptible jus cogens violations. ${ }^{97}$ In the Bankovic Case, the Court has expressly referred to Article 31, para. 3 lit. c of the Vienna Convention on the Law of Treaties in order to emphasize the importance of other international agreements for the interpretation and application of the ECHR. ${ }^{98}$

\section{The Cases of Agim Behrami and Bekir Behrami v. France and Ruzhdi Saramati v. France, Germany, Norway}

Although dealing with a completely different context, a recent decision of the ECtHR may be interesting in this regard. The joined cases of Behrami and Saramati concern the responsibility for alleged violations of human rights law through the UN and NATO authorities in Kosovo. The core question was whether ECHR Contracting States could be held responsible for their actions within the context of UNMIK and KFOR

96 Hoffmeister, Frank, op. cit., note 27, p. 448; Bulterman, Mielle, op. cit., note 52, p. 767.

97 ECtHR, al-Adsani $v$. The United Kingdom, Application No. 35763/97, Grand Chamber, Judgment of 21 November 2001, ECHR 2001-XI, 79, paras. 52 et seq.

98 ECtHR, Bankovic and others v. Belgium and others, Application no. 52207/99, Grand Chamber, Decision of 12 December 2001, ECHR 2001-XII, 333, paras. 57 et seqq. 
administration. The Court answered in the negative. It is noteworthy that the Court was obviously concerned to emphasize the importance of the UN. It could have paused after its consideration that the UN needs to be seen as a separate legal entity, enjoys legal personality and that therefore wrongful actions can only be attributed to the UN itself and not to the contracting States acting in concreto. ${ }^{99}$ However, the Court went one step further. It pointed out:

The Convention cannot be interpreted in a manner which would subject the acts and omissions of Contracting Parties which are covered by UNSC Resolutions and occur prior to or in the course of such missions, to the scrutiny of the Court. To do so would be to interfere with the fulfilment of the UN's key mission in this field including, as argued by certain parties, with the effective conduct of its operations. It would also be tantamount to imposing conditions on the implementation of a UNSC Resolution which were not provided for in the text of the Resolution itself. This reasoning equally applies to voluntary acts of the respondent States such as the vote of a permanent member of the UNSC in favour of the relevant Chapter II Resolution. ${ }^{100}$

How can those words be interpreted? We need to take into account the following paragraph of the judgment where the Court drew a distinction between the case it considered and the Bosphorus case. In the latter: "the impugned act... had been carried out by the respondent State authorities, on its territory and following a decision by one of its Ministers". ${ }^{101}$

It is indeed important to note that a large portion of the ruling in the Bosphorus case was based on the margin of appreciation left for Ireland in the application of the respective UN Security Council resolutions and EC Regulations, as was highlighted in the joint concurring opinion of Judges Rozakis et al. ${ }^{102}$ As applied to the problem of legal protection against targeted sanctions this could lead to a nuanced approach, incidentally one which is already followed by the EC Courts: Where there is no

99 ECtHR, Behrami and Saramati, op. cit., note 28, para. 141.

100 Ibidem, para. 149.

101 Ibidem, para. 150.

102 ECtHR, Bosphorus v. Ireland, Joint Concurring Opinion of Judges Rozakis, Tulkens, Traja, Botoucharova, Zagrebelsky and Garlicki, reprinted in 26 Human Rights Law Journal 2005, at p. 37. 
margin of appreciation for the implementing organisation, i. e. within the confines of the so-called "1267-Regime", there is only a very limited degree of judicial scrutiny. However, where the listing of the targeted person is effectuated not on the UN level, but rather on the basis of a general obligation to undermine the financing of international terrorism, i.e. in the situation the "1373-Regime" envisages - the degree of scrutiny is heightened.

The parts of the judgment pertaining to the UN security system do not do away with the requirement of equivalent protection. However, as we have seen, the test is not a rigid one. There seems to be room for balancing processes which can take into account of the fundamental importance the international legal system is ascribing to the UN Charter as its central document in general terms and to the fight against terrorism as one of today's prime tasks for the UN Charter system of collective security. That the ECtHR may actually be willing to do so is shown by the careful manner in which it assessed the consequences of an implied review of UN Security Council action in the Behrami and Saramati cases.

\section{CONCLUDING OBSERVATIONS}

In sum, the European Courts seem to have found a reasonable approach towards the fundamental rights implications of UN Security Council targeted sanctions. They have neither been overly self-asserting in the way that they would have tried to impose European standards on the UN Security Council nor have they shown complete deference to the organ with primary responsibility for the maintenance of international peace and security. They have highlighted limits which the UN Security Council needs to respect at all times. Where they have made out a possibility for more far-reaching human rights protection, they have effected it as the ECFI did in the OMI case. Arguably, this case puts additional political pressure on the Security Council and especially the European States which are represented therein to reflect on the ways and means targeted sanctions are imposed and administered. Although the differences between the "1267-Regime" and "1373-Regimes" are perfectly understandable to the international lawyer, they may not be so in the eyes of the general public. 
Nonetheless, the ECFI has been heavily criticized for not affording enough legal protection against the UN Security Council. ${ }^{103}$ It is striking that the discussion on the targeted sanctions often portrays an overly idealistic picture of the international legal system only to contrast it with the Security Council contravening all ideals of justice. This is simplistic and may very well be just wrong. The discussion suffers from a lack of serious work on the legal limits which actually do exist for the UN Security Council. Even if the Security Council would be bound by general human rights law, the sanctions regimes arguably would not violate human rights law. First of all, a general standard of protection would need to be established which would need to focus on a universal human rights standard. ${ }^{104}$ Second, all human rights which are not non-derogable (or albeit jus cogens) are subject to a balancing process with competing policy objectives. ${ }^{105}$ Third, the Security Council should also have the opportunity to derogate from human rights. ${ }^{106}$ This possibility is provided for in human rights treaties. ${ }^{107}$ It would be curious not to give this opportunity to the organ of the international community which is par excellence responsible for the dealing with emergency situations. ${ }^{108}$ If we take all this into account, the standard of human rights protection in the case of targeted sanctions decided upon by the Security Council would probably not exceed the degree of judicial review the ECFI was willing to engage in

103 See the contributions referred to in note 74.

104 For a comprehensive account on universal human rights standards with respect to due process see Fassbender, Bardo, "Targeted Sanctions Imposed by the UN Security Council and Due Process Rights - A Study Commissioned by the UN Office of Legal Affairs and Follow-up Action by the United Nations", 3 International Organizations Law Review 2006, pp. 437-485.

105 See, for example, Article 29, para. 2 of the Universal Declaration of Human Rights, Articles 8, para. 2 and 9, para. 2 of the European Convention on Human Rights, Article 12, para. 3 of the International Covenant on Political and Civil Rights, Article 32, para. 2 of the American Convention on Human Rights, Article 27, para. 2 of the Banjul Charta.

106 De Wet, Erika and Nollkaemper, André, op. cit., note 4, at p. 179.

107 See, for example, Article 4 of the International Covenant on Civil and Political Rights, Article 15 of the European Convention on Human Rights, Article 27 of the American Convention on Human Rights.

108 On the character of the Security Council as dealing with emergency situations see De Wet, Erika, op. cit., note 50, p. 202; Lysen, Göran, "Targeted UN Sanctions: Application of Legal Sources and Procedural Matters", 72 Nordic Journal of International Law 2003, pp. 291-304, p. 296. 
right now: it is the standard of human rights protection which is envisaged by jus cogens. ${ }^{109}$

This assessment is de lege lata. De lege ferenda, the sanctions regimes need to be changed. They are prone to undermine the legitimacy of the UN system of collective security. ${ }^{110}$ They are also discouraging belief in the progress of human rights protection. In comparison to other fields of the fight against terrorism where human rights are clearly violated this is not the case in our example. Mention should be made of the ongoing changes in the sanctions regimes: Exceptions on humanitarian grounds have been introduced ${ }^{111}$ and as the latest innovation a focal point has been created to which individuals or entities listed can communicate. ${ }^{112}$ However, this does not help the uneasiness every sensitive international lawyer will share when looking at the cases. In addition, there is the inherent danger that domestic courts will not be willing to accept this lowering of the protection of fundamental rights. In fact, the situation that Security Council resolutions are implemented by another international organization is a peculiar one. It allows for an application of the UN Security Council resolutions due to their superior character, be it on the basis of Article 103 of the Charter or of Article 307 TEC. The construction of the Community legal system then allows for direct application in the domestic sphere which is not checked upon by domestic courts. However, there is a "thin red line" 113 which separates the precedence the Community law takes from the situation in which control by the domestic courts resurfaces. In other countries, the resolutions are subject to domestic review in the first place. Although international law would only allow for a non-application of UN Security Council resolutions in very limited cases, the constitutions of most States do not accord precedence of the UN Charter over domestic constitutional law. Consti-

109 For an overview on non-derogable rights in international law see von Schorlemer, Sabine, "Human Rights: Substantive and Institutional Implications of the War Against Terrorism", 14 European Journal of International Law 2003, pp. 265-282, at p. 278.

110 Bianchi, Andrea, "Assessing the Effectiveness of the UN Security Council's Anti-Terrorism Measures: the Quest for Legitimacy and Cohesion", 17 European Journal of International Law 2006, pp. 881-919.

111 UN Doc. S/RES/1452 (2002).

112 UN Doc. S/RES/1730 (2006).

113 This expression is borrowed from Simma, Bruno, "NATO, the UN and the Use of Force: Legal Aspects”, 10 European Journal of International Law 1999, pp. 1-22, at p. 22. 
tutional courts would thus in most cases have no option as to apply their domestic constitutional law and to accept a breach of international legal obligations in order to uphold their constitutional orders. ${ }^{114}$ In order to avoid this situation, it is highly desirable that the sanctions regimes will be amended in a manner which quietens criticism as to their conformity with broader standards of the rule of law.

114 Fassbender, Bardo, "Article 19 Abs. 4 GG als Garantie innerstaatlichen Rechtsschutzes gegen Individualsanktionen des UN-Sicherheitsrates", 132 Archiv des Öffentlichen Rechts 2006, pp. 257-286, p. 284. 